\title{
PELATIHAN DESAIN DAN MANAJEMEN JARINGAN KOMPUTER PADA ANGGOTA ORGANISASI PEGERAKAN MAHASISWA ISLAM INDONESIA (PMII) KABUPATEN BANJAR
}

\author{
Al Fath Riza Kholdani ${ }^{*}$, Tri Wahyu Qur'ana ${ }^{2}$ \\ [tanda $\left({ }^{*}\right)$ khusus untuk corresponding author] \\ 1,2 Jurusan Teknik Informatika, Universitas Islam Kalimantan MAB Banjarmasin \\ 1kholdanialfath@gmail.com \\ 2twqurana@gmail.com
}

\begin{abstract}
Abstrak
Jaringan komputer adalah sistem yang terdiri dari komputer-komputer serta piranti-piranti yang saling terhubung sebagai satu kesatuan. Jaringan komputer berguna untuk berbagi perangkat keras dan perangkat lunak serta koneksi Internet. Penggunaan jaringan oleh masyarakat luas akan menyebabkan timbulnya masalah-masalah etika, sosial, politik dan ekonomi yang tak terelakkan. Pemanfaatan desain dan manajemen jaringan komputer/internet mampu menjadikan ladang usaha ekonomi kreatif berbasis teknologi informasi. Keahlian tentang jaringan komputer dapat diimplimentasikan diberbagai bidang misalkan pembangunan jaringan internet, perbaikan jaringan, keamanan jaringan, control server dan sebagainya. Permasalahan yang dihadapi selama ini adalah bagaimana menyelesainkan masalah dalam dunia jaringan komputer yang semakin kompleks. Pergerakan Mahasiswa Islam Indonesia atau yang disingkat dengan PMII adalah sebuah organisasi kemahasiswaan. Mahasiswa sebagai pemuda generasi penerus bangsa, perlu memahami dan memiliki kemampuan dalam hal tersebut, bukan hanya sebagai pengguna pasif saja tetapi juga harus aktif, Sisi lain juga mampu dijadikan sebagai bagian dari penggerak ekonomi kreatif dan memiliki kemammpuan bagaimana cara yang efektif dan efisien dalam menyelesaikan permasalahan jaringan komputer di kantor atau sekretariat.
\end{abstract}

Kata Kunci: Internet, Jaringan, Komputer

\section{Pendahuluan}

Pemanfaatan desain dan manajemen jaringan komputer/internet mampu menjadikan ladang usaha ekonomi kreatif berbasis teknologi informasi. Keahlian tentang jaringan komputer dapat diimplimentasikan diberbagai bidang misalkan pembangunan jaringan internet, perbaikan jaringan, keamanan jaringan, control server dan sebagainya. Hal tersebut didasarkan pada pemahaman dan kemampuan dalam pembangunan, pengembangan serta pengelolaan jaringan komputer. Mahasiswa sebagai pemuda generasi penerus bangsa, perlu memahami dan memiliki kemampuan dalam hal tersebut, bukan hanya sebagai pengguna pasif saja tetapi juga harus aktif, Sisi lain juga sebagai bagian dari penggerak ekonomi kreatif. 
Permasalahan yang sering timbul adalah, bagaimana melakukan pengelolaan jaringan komputer yang semakin kompleks. Semakin banyak pengguna yang terkoneksi internet baik pada kantor atau sekretariat PMII Kabupaten Banjar melalui wifi, menjadikan pembagian bandwith tidak merata, akhirnya koneksi lambat atau lelet. Belum lagi permasalahan pengguna yang iseng dengan memotong koneksi jaringan pengguna yang lain. Sisi lain dari malasah koneksi adalah virus, yang akhirmya semua pengguna jaringan komputer tersebut kemungkinan akan teriveksi virus. Khalayak sasaran dari kegiatan pengabdian kepada masyarakat adalah anggota PMII Kab.Banjar berjumlah 20 orang yang terlibat dalam pengelolaan pengembangan sistem jaringan komputer yang ada dikantor atau sekretariat. Anggota PMII Kab.Banjar ini terdiri dari mahasiswa yang berasal dari berbagai macam Universitas ataupun Perguruan Tinggi lainnya baik lakilaki mapun perempuan.

\section{Metode Pelaksanaan}

Metode pelaksanaan kegiatan pengabdian kepada masyarakat dilaksanakan melalui pelatihan dengan pemanfaatan modul yang telah disediakan yaitu dengan metode teori pembelajaran dan praktik langsung ditempat. Selain itu, mereka juga diberikan contoh dan kasus serta simulasi bagaimana desain dan manajemen terhadap dunia jaringan komputer.
Melalui kegiatan pengabdian kepada masyarakat, pelatihan kepada peserta para anggota organisasi PMII Kabupaten Banjar dilakukan oleh beberapa instruktur profesional dibidangnya dengan materi pelatihan sebagai berikut:

1. Pengenalan Jaringan Komputer

2. Desain dan Topologi Jaringan Komputer

3. Media jaringan komputer

4. Manajemen dan keamanan jaringan komputer

\section{Tinjauan Pustaka}

\section{A. Jaringan Komputer}

Menurut Komputer, W. (2010), Jaringan Komputer adalah sistem yang terdiri dari komputer-komputer, serta piranti-piranti yang saling berhubungan sebagai satu kesatuan. Dengan dihubungkannya prantipiranti tersebut, alhasil dapat saling berbagi sumber daya antar yang satu dan yang lainnya.

Selain itu, menurut Syafrizal, M. (2005), Jaringan komputer adalah himpunan "interkoneksi" antara dua komputer atau lebih yang terhubung dengan media transmisi kabel atau nirkabel (wireless). Bila sebuah komputer dapat membuat komputer lainnya restart, shutdown atau melakukan kontrol lainnya, maka komputer tersebut bukan autonomous.

\section{B. Desain dan Topologi Jaringan}

Menurut Supriyadi, A., \& Gartina, D. (2007), Topologi jaringan komputer adalah suatu cara menghubungkan komputer yang 
satu dengan komputer lainnya sehingga membentuk jaringan. Cara yang saat ini banyak digunakan adalah bus, token ring, dan star. Dalam suatu jaringan komputer jenis topologi yang dipilih akan mempengaruhi kecepatan komunikasi. Untuk itu maka perlu dicermati kelebihan/keuntungan dan kekurangan / kerugian dari masing - masing topologi berdasarkan karakteristiknya.

\section{Hasil Kegiatan}

Kegiatan pengabdian kepada masyarakat dilakukan dalam beberapa tahapan yaitu Persiapan kemudian pembukaan oleh Ketua tim pengabdian pada sekretariat PMII Kabupaten Banjar. Setelah tahapan tersebut selesai, kemudian masuklah pada tahap pelatihan mengenai pengenalan jaringan komputer, desain dan topologi jaringan komputer, media jaringan komputer dan manajemen keamanan jaringan.

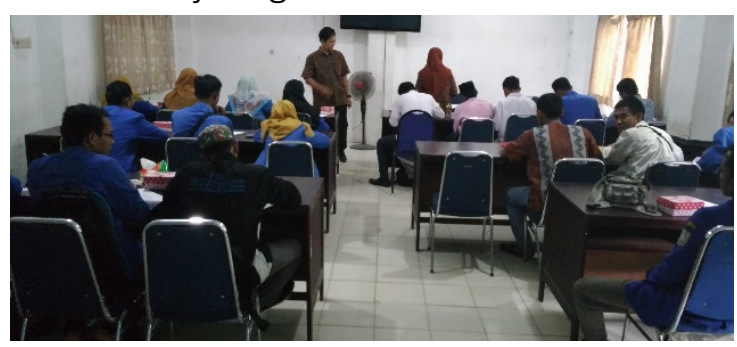

Gambar 1: Persiapan dan Pembukaan Kegiatan Pengabdian Kepada masyarakat

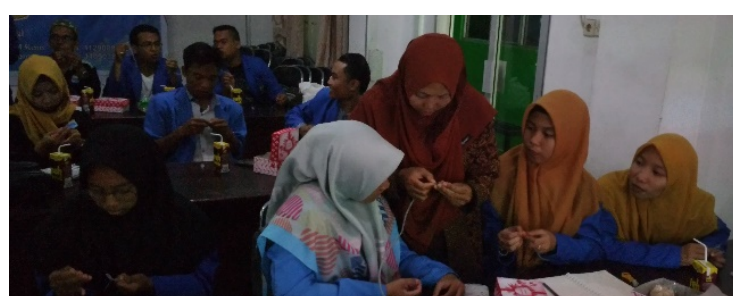

Gambar 2: Tutor langsung mempraktikkan dengan peserta kegiatan.

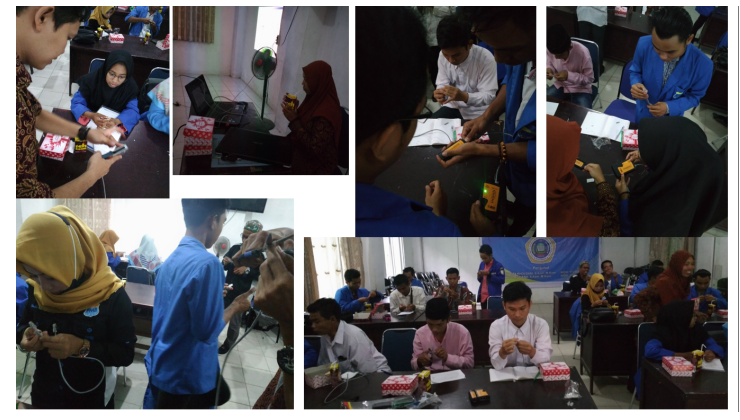

Gambar 3: Peserta dibantu oleh Tim

Pengabdian Kepada Masyarakat

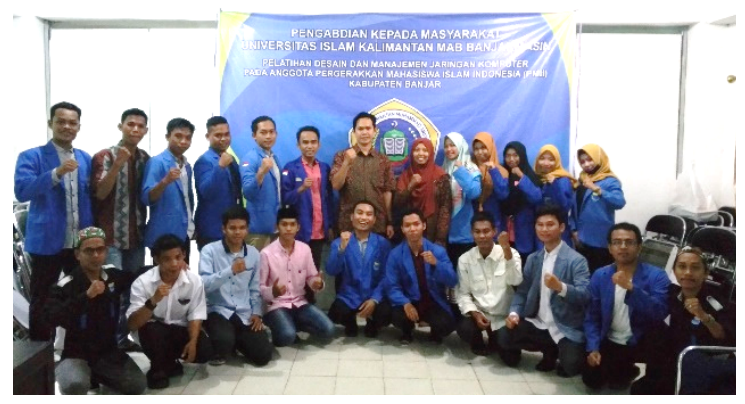

Gambar 4: Foto bersama selesai kegiatan.

Pada tahapan akhir kegiatan pelatihan, peserta dipersilakan untuk berfoto bersama, sebagai wujud kerjasama dan dokumentasi telah terselesaikannya salah satu Tri Dharma Perguruan Tinggi.

\section{Evaluasi Kegiatan}

Kegiatan Pengabdian Kepada Masyarakat yang telah dilaksanakan pada anggota organisasi Pergerakan Mahasiswa Islam Indonesia (PMII) Kabupaten Banjar berjalan dengan sangat baik dan lancar. Semua peserta kegiatan terlibat sangat aktif dan antusias dalam diskusi tanya jawab serta mempraktekkan langsung apa yang diajarkan. Terlihat perbedaan yang mencolok sebelum dan setelah diberikan pelatihan. Hal tersebut dapat terlihat dari diagram hasil kuesioner pre test dan post Jurnal Pengabdian Kepada Masyarakat MEDITEG Volume 4, Nomor 1, September 2019 Copyright $\odot 2019$ Jurnal Pengabdian Kepada Masyarakat MEDITEG 
test yang dibagikan kepada peserta kegiatan praktikum.

\section{PRE TEST}

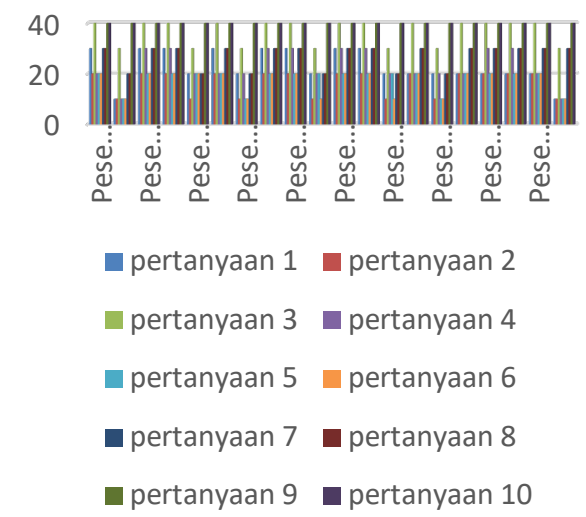

Gambar 5: Diagram Pre Test Hasil Kuesioner

\section{POST TEST}

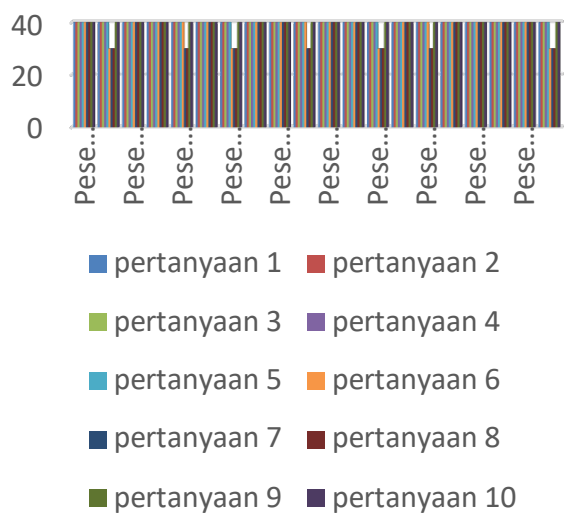

Gambar 6: Diagram Post Tes Hasil Kuesioner

Terlihat dari Gambar 5 dan Gambar 6 tersebut perubahan pengetahuan dan pemahaman para peserta setelah materi pelatihan yang diajarkan. Beberapa hal yang terlihat secara langsung diantaranya adalah mereka mampu memahami dengan benar istilah jaringan komputer, desain dan manajemen jaringan serta manfaat yang ditimbulkan. Peserta juga terlihat mampu dalam melakukan praktik membuat kabel Cross dan Straight, konfigurasi jaringan komputer, mengamankan data dalam jaringan komputer sampai remote desktop connection. Dari semua peserta kegiatan, tidak terlihat ada yang lebih unggul dalam pengetahuan jaringan komputer. Hal tersebut dikarenakan latar belakang pendidikan mereka yang bukan dari keilmuan komputer, akan tetapi setelah kegiatan berlangsung mereka mampu mengikuti hingga mempraktikan apa yang diberikan dalam pelatihan walaupun masih ada human error. Peserta yang didelegasikan untuk mengikuti kegitan pengabdian kepada masyarakat ternyata melebihi dari target, ada 21 Orang yang berhadir saat acara berlangsung.

\section{KesIMPULAN}

Hasil kegiatan pengabdian kepada masyarakat yang telah dilaksanakan pada Anggota Organisasi PMII Kab. Banjar dapat diambil beberapa kesimpulan diantaranya sebagai berikut :

1. Peserta Pengabdian Kepada Masyarakat mampu memahami hingga mempraktikkan apa yang diberikan dalam pelatihan, hal tersebut tergambar pada hasil kuesioner yang diberikan dan terlihat secara nyata, walaupun masih ada kesalahan.

2. Peserta mampu menyelesaiakan permasalahan konfigurasi jaringan yang selama ini terjadi pada PMII 
Kabupaten Banjar, hal tersebut terlihat dari pertanyaan-pertanyaan dan diskusi serta langsung mereka praktikkan saat pelatihan berlangsung.

3. Semua peserta mengetahui manfaat yang luarbiasa dari keilmuan jaringan komputer, hal ini ditandai dengan salah satu contohnya penggunaan aplikasi remote desktop connection.

4. Semua peserta sangat antusias mengikuti kegiatan ini karena materi yang diberikan sangat bermanfaat dan sesuaian zaman, hal tersebut terbukti dengan keinginan mereka untuk diberikan pelatihan lanjutan tentang nirkabel.

\section{Daftar Pustaka}

Komputer, W. (2010). Cara Mudah Membangun Jaringan Komputer \& Internet. MediaKita.

Mulyanta, E. S. (2005). Pengenalan Protokol Jaringan Wireless Komputer. Penerbit Andi.

Purbo, W. O., \& Wiharjito, T. (2000). Buku Pintar Internet Keamanan Jaringan Internet. PT Elex Media Komputindo, Jakarta.

Supriyadi, A., \& Gartina, D. (2007). Memilih Topologi Jaringan Dan Hardware Dalam Desain Sebuah Jaringan Komputer. Informatika, 16(2), 10371053.

Susanto, S. (2009). Manajemen jaringan komputer. Jurnal Transformatika, 6(2), 67-77.
Syafrizal, M. (2005). Pengantar jaringan komputer. Penerbit Andi. 